\title{
Gene Product Variation Site
}

National Cancer Institute

\section{Source}

National Cancer Institute. Gene Product Variation Site. NCI Thesaurus. Code C118426.

The amino acid position that is substituted in a gene product variant. 